\title{
Impact of socio-economic growth and economic potential on the sustainable development of region
}

\author{
Valery Chichkanov ${ }^{1, *}$, Alexander Kuklin ${ }^{2}$, Sergey Okhotnikov ${ }^{3}$, and Ilia Korobkov ${ }^{4}$ \\ ${ }^{1}$ Russian Academy of Sciences, 32-a, Leninsky prospect, 119991, Moscow, Russia \\ ${ }^{2}$ Ural Federal University named after the first President of Russia B.N. Yeltsin, 19, Mira str., 620002, \\ Ekaterinburg, Russia \\ ${ }^{3}$ Oxford Language Center, 11, Titova str., 620085, Ekaterinburg, Russia \\ ${ }^{4}$ JSC Vostochny Veter, 20a, Lukinykh str., 622039, Ekaterinburg, Russia
}

\begin{abstract}
This article presents a methodological approach to assessing the real wellbeing of citizens in the territory of their residence. An attempt was made to comprehensively assess wellbeing, taking into account the economic factors of potential and growth. Moreover, under crisis conditions, these factors may demonstrate a different dynamic. The ongoing economic uncertainly inherent in the development of Russian regions has intensified with the unfolding of the Covid-19 pandemic. The structural heterogeneity of the domestic economy, manifested in the underfunding of human development, led to an increase in poverty, population decline and, ultimately, to a decrease in welfare. The principle of catch-up modernization has not justified itself for over almost three decades of its application. We propose a diagnostic approach to assessing the state of a region's economy taking into account the dynamics of indicators and impulse response behaviour of turning points. In order to provide a timely manner of calculations, techniques of express diagnostics were used, which enabled estimation of the development trajectory in the context of a certain crisis type. The proposed methodology was tested using the example of the Ural Federal District.
\end{abstract}

\section{Introduction}

According to its potential, Russia is one of the richest countries in the world. Demonstrating a fairly high stability of socio-economic development under the conditions of multivariate crises, Russia has all the conditions for economic growth.

An important indicator of the level of socio-economic development is the wellbeing of citizens in the territory of their residence. Our latest research confirmed that a real picture of a region's socio-economic state could be obtained taking into account corrective modules, using new nonlinear models of diagnostics and identifying hidden (latent) characteristics. In

* Corresponding author: vpchichkanov@yandex.ru 
other words, the exclusive reliance of available statistics is not always accurate. Therefore, in this article, we rely on our developments concerning economic tomography, express diagnostics, probability density function and the CES function method.

\section{Brief literature review}

Last periods of development of the Russia were accompanied by various management errors, leading to ineffective responses to threats and challenges. It is necessary to highlight the deformed structure of the economy, the growth of poverty, the decline in the quality of life, sanctions from other states, the lag in the development of energy-saving technologies. The Covid - 19 pandemic was added to the named threats and challenges [1].

As a result, Russian economy has failed to reach the planned indicators of economic development. Therefore, the state and prospects of socio-economic development should be discussed from the standpoint of citizen wellbeing, adjusted to the level of potential and economic growth.

In crisis periods, states should implement strategies aimed at saving people, harmonizing their lives, providing benefits and possibilities for personal development. We consider this process through the lens of improving the wellbeing of citizens in the territory of their residence in conjunction with the following two components.

At the level of citizens: providing the possibilities for obtaining moral, intellectual, aesthetic and religious education; providing the population with the benefits necessary for life; creating opportunities for the development of human abilities and maintaining physical and mental health.

At the level of the territory of residence: providing the socio-economic system with the necessary resources and infrastructure; balanced opposition between the imperatives of economic efficiency and social justice; sufficient participation of the state in the life of the population) [2].

The study is focused on the wellbeing of a particular individual, i.e., a person who, through activity, learns and changes the world. This process, manifested in social relations, achievement of a certain level of professional and cultural education, cannot be considered separately from the territory of residence. Personality is a social and systemic quality acquired by an individual in the process of activity and communication.

An analysis of citizens' wellbeing in the territory of their residence (using the example of the subjects of the Ural Federal District (UFD) according to the most significant crisis modules) showed that, during the last 5 years, the UFD subjects remained in the pre-crisis PC3 or crisis $\mathrm{C} 1$ zones. The dynamics of indicators was assessed across the following range of changes: $\mathrm{N}-$ a relatively normal situation; $\mathrm{PC} 1$ - the initial stage of the pre-crisis; PC2 the developing stage of the pre-crisis, $\mathrm{PC} 3$ - the critical stage of the pre-crisis threatening a transition to the crisis zone; $\mathrm{C} 1$ - an unstable stage of the crisis; $\mathrm{C} 2$ - the threatening stage of the crisis; $\mathrm{C} 3$ - the emergency stage of the crisis.

\subsection{Living standards of the population}

All the UFD subjects were in the $\mathrm{C} 1-\mathrm{C} 2$ crisis zone, which could be explained by the low average income per capita. A comparison between the average pension and the minimum subsistence level showed the extreme stage of the $\mathrm{C} 3$ crisis.

In terms of the degree of poverty, the position of all UFD subjects was unstable: Chelyabinsk Oblast (C1) and the Yamalo-Nenets Autonomous Okrug (YNAO) (C2). In the total consumer expenditures of the population, expenditures on the purchase of food and 
alcoholic beverages increased significantly (over 35\%), as well as the share of expenditures on housing and communal services in the average per capita income.

\subsection{Population quality}

The illusion of overcoming the "Russian cross" (burden) has vanished. The worst situation was observed in the Kurgan Oblast, where the natural population growth rate decreased to 6.1 people per 1000 people in 2019, compared to 3.2 and 2.7 people per 1000 people in the Chelyabinsk and Sverdlovsk Oblasts, respectively. This trend could be explained by a high level of morbidity (tuberculosis, HIV infection, drug addiction).

The current level of drug use leads to the conclusion that additional anti-drug measures should be taken $[3,4,5]$. According to our calculations, the aggregate values of the socioeconomic costs of drug distribution (losses from mortality due to drug use; as a result of crimes committed by drug users or with their complicity; costs of drug addiction treatment and related diseases; costs of maintaining state institutions that control and regulate drug trafficking; expenses of drug users for the purchase of drugs; expenses for the implementation of regional and municipal anti-drug programmes) amounted to more than 130 billion roubles in 2019 in the Ural Federal District. For the most populated UFD regions, these figures were 43.3 billion roubles for the Sverdlovsk Oblast and 29.4 billion roubles for the Chelyabinsk Oblast.

\section{Methods and data: dynamics of the indicators used to assess citizens' wellbeing in the territory of their residence}

When describing the model, we will proceed from the following assumptions:

- indicators of economic potential and development have hidden latent characteristics in the time series themselves;

- values for crises (one-year, three-year, and five-year) are described when passing through one level;

- critical changes (sanctions, epidemics) are considered as a function of external influence.

Let us consider the behaviour of indicators during the transition between crisis levels, taking into account the rate of changes (Table 1).

Table 1. Main types of crisis transitions (standard patterns selected to characterize 9 types of crises).

\begin{tabular}{|c|c|c|}
\hline Transition type & Main characteristics & Description \\
\hline \multicolumn{3}{|c|}{ 1-year crisis } \\
\hline $\mathrm{PC} 3 \rightarrow \mathrm{C} 1(1 / 3) \rightarrow \mathrm{PC} 3$ & $\begin{array}{c}\text { Rate of entrance: } \\
0.334 \leq \mathrm{V} \leq 0.466 \\
\text { Rate of return: } \\
\mathrm{V} \leq 0.466\end{array}$ & $\begin{array}{l}\text { Low-rate dynamics with } \\
\text { entering the } \mathrm{C} 1 \text { zone by no } \\
\text { more than } 1 / 3\end{array}$ \\
\hline $\mathrm{PC} 3 \rightarrow \mathrm{C} 1 \rightarrow \mathrm{PC} 3$ & $\begin{array}{c}\text { Rate of entrance: } \\
0.466 \leq \mathrm{V} \leq 0.733 \\
\text { Rate of return: } \\
\mathrm{V} \leq 0.733\end{array}$ & $\begin{array}{l}\text { High-rate dynamics with } \\
\text { entering the } \mathrm{C} 1 \text { zone by over } \\
\text { than } 1 / 3\end{array}$ \\
\hline $\mathrm{PC} 3 \rightarrow \mathrm{C} 2 \rightarrow \mathrm{PC} 3$ & $\begin{array}{c}\text { Rate of entrance: } \\
0.733 \leq \mathrm{V} \leq 1.333 \\
\text { Rate of return: } \\
\mathrm{V} \leq 0.733 \\
\end{array}$ & $\begin{array}{c}\text { High-rate dynamics with } \\
\text { entering the } \mathrm{C} 2 \text { zone by over } \\
\text { than } 1 / 3\end{array}$ \\
\hline
\end{tabular}




\begin{tabular}{|c|c|c|}
\hline $\mathrm{PC} 3 \rightarrow \mathrm{C} 1 \rightarrow \mathrm{C} 1 \rightarrow \mathrm{C} 1 \rightarrow \mathrm{PC} 3$ & $\begin{array}{c}\text { Rate of entrance: } \\
0.001 \leq \mathrm{V} \leq 0.166 \\
\text { Rate of return: } \\
\mathrm{V} \leq 0.733\end{array}$ & $\begin{array}{l}\text { 3-year crisis leading to } \\
\text { entering the } \mathrm{C} 1 \text { zone but } \\
\text { without reaching the } \mathrm{C} 2 \text { zone }\end{array}$ \\
\hline $\mathrm{PC} 3 \rightarrow \mathrm{C} 1 \rightarrow \mathrm{C} 2 \rightarrow \mathrm{C} 1 \rightarrow \mathrm{PC} 3$ & $\begin{array}{c}\text { Rate of entrance: } \\
0.166 \leq \mathrm{V} \leq 0.399 \\
\text { Rate of return: } \\
\mathrm{V} \leq 0.733 \\
\end{array}$ & $\begin{array}{c}\text { 3-year crisis leading to } \\
\text { entering the } \mathrm{C} 1 \text { zone but } \\
\text { without reaching the } \mathrm{C} 2 \text { zone }\end{array}$ \\
\hline $\mathrm{PC} 3 \rightarrow \mathrm{C} 2 \rightarrow \mathrm{C} 3 \rightarrow \mathrm{C} 2 \rightarrow \mathrm{PC} 3$ & $\begin{array}{c}\text { Rate of entrance: } \\
0.401 \leq \mathrm{V} \leq 1.133 \\
\text { Rate of return: } \\
\mathrm{V} \leq 1.133 \\
\end{array}$ & $\begin{array}{l}\text { 3-year crisis leading to } \\
\text { entering the } \mathrm{C} 1 \text { zone but } \\
\text { without reaching the } \mathrm{C} 2 \text { zone }\end{array}$ \\
\hline \multicolumn{3}{|c|}{ 5-year crisis } \\
\hline $\begin{array}{l}\mathrm{PC} 3 \rightarrow \mathrm{C} 1 \rightarrow \quad \mathrm{C} 2 \rightarrow \quad \mathrm{C} 2 \rightarrow \\
\mathrm{C} 2 \rightarrow \mathrm{PC} 3\end{array}$ & $\begin{array}{l}\text { Rate of entrance: } \\
0.401 \leq \mathrm{V} \leq 1.133 \\
\text { Rate of return: } \\
\mathrm{V} \leq 1.133\end{array}$ & $\begin{array}{l}\text { Smooth dynamics of the } \\
\text { indicator leading to entering } \\
\text { the } \mathrm{C} 1 \text { zone followed by } \\
\text { low-rate changes across the } \\
\mathrm{C} 2 \text { zone }\end{array}$ \\
\hline
\end{tabular}

In order to trace structural changes in the indicators, we assessed not only their modulus values but also their direction.

\subsection{Rate field of the indicators}

This characteristic includes the relative change in the indicator per unit of time, i.e., the time derivative $V(t)=d X(t) / d t[6,7]$, allowing sharp jumps in the indicator to be captured (for example, from the $\mathrm{PC}$ to $\mathrm{C}$ level or vice versa). The dependence of the indicator rate on the indicator value makes it possible to identify the most probable values of the indicator (equilibrium points).

Table 2. Possible high-speed transitions of indicators within the templates of standard crises.

\begin{tabular}{|c|c|c|c|}
\hline $\begin{array}{c}\text { Transition } \\
\text { type }\end{array}$ & Rate & $\begin{array}{c}\text { Transition } \\
\text { type }\end{array}$ & Rate \\
\hline $\mathrm{N} \rightarrow \mathrm{PC} 1$ & $0.001 \leq \mathrm{V} \leq 0.332$ & $\mathrm{PC} 2 \rightarrow \mathrm{PC} 3$ & $0.001 \leq \mathrm{V} \leq 0.666$ \\
\hline $\mathrm{N} \rightarrow \mathrm{PC} 2$ & $0.333 \leq \mathrm{V} \leq 0.665$ & $\mathrm{PC} 2 \rightarrow \mathrm{C} 1$ & $0.335 \leq \mathrm{V} \leq 1.066$ \\
\hline $\mathrm{N} \rightarrow \mathrm{PC} 3$ & $0.666 \leq \mathrm{V} \leq 0.999$ & $\mathrm{PC} 2 \rightarrow \mathrm{C} 2$ & $0.735 \leq \mathrm{V} \leq 1.466$ \\
\hline $\mathrm{N} \rightarrow \mathrm{C} 1$ & $1 \leq \mathrm{V} \leq 1.399$ & $\mathrm{PC} 2 \rightarrow \mathrm{C} 3$ & $1.135 \leq \mathrm{V}$ \\
\hline $\mathrm{N} \rightarrow \mathrm{C} 2$ & $1.4 \leq \mathrm{V} \leq 1.799$ & $\mathrm{PC} 3 \rightarrow \mathrm{C} 1$ & $0.001 \leq \mathrm{V} \leq 0.733$ \\
\hline $\mathrm{N} \rightarrow \mathrm{C} 3$ & $1.8 \leq \mathrm{V}$ & $\mathrm{PC} 3 \rightarrow \mathrm{C} 2$ & $0.401 \leq \mathrm{V} \leq 1.133$ \\
\hline $\mathrm{PC} 1 \rightarrow \mathrm{PC} 2$ & $0.001 \leq \mathrm{V} \leq 0.664$ & $\mathrm{PC} 3 \rightarrow \mathrm{C} 3$ & $0.801 \leq \mathrm{V}$ \\
\hline $\mathrm{PC} 1 \rightarrow \mathrm{PC} 3$ & $0.334 \leq \mathrm{V} \leq 0.998$ & $\mathrm{C} 1 \rightarrow \mathrm{C} 2$ & $0.001 \leq \mathrm{V} \leq 0.799$ \\
\hline $\mathrm{PC} 1 \rightarrow \mathrm{C} 1$ & $0.668 \leq \mathrm{V} \leq 1.398$ & $\mathrm{C} 1 \rightarrow \mathrm{C} 3$ & $0.401 \leq \mathrm{V}$ \\
\hline $\mathrm{PC} 1 \rightarrow \mathrm{C} 2$ & $1.068 \leq \mathrm{V} \leq 1.798$ & $\mathrm{C} 2 \rightarrow \mathrm{C} 3$ & $0.001 \leq \mathrm{V}$ \\
\hline $\mathrm{PC} 1 \rightarrow \mathrm{C} 3$ & $1.468 \leq \mathrm{V}$ & & \\
\hline
\end{tabular}

Table 2 shows 21 basic schemes of transitions between the crisis levels and the interval characteristics of their rates.

\subsection{Stability function (crisis)}

Let us introduce the following quadratic form (1) for the indicator value in the form:

$$
\Delta(t)=\frac{1}{2}(X(t))^{2} \geq 0
$$


The derivative of this function has the form $d \Delta(t) / d t=X(t)(d X(t) / d t)$ [8]. Both functions can be considered as an analogue of the Lyapunov function, indicating the stable and unstable behaviour of indicators and thereby capturing the transitions between the crisis levels. Sustainable development of a trend within one level corresponds to cases $\Delta(t) \geq 0$ and $d \Delta(t) / d t<0$ (sign-negative function). In cases of unstable behaviour of an indicator, i.e. in order to capture the transitions to the levels $\mathrm{C} 1, \mathrm{C} 2$ and $\mathrm{C} 3$, it is essential that the derivative of the stability function took positive values $d \Delta(t) / d t>0$.

\subsection{Impulse characteristics}

Let us introduce a characteristic linking the indicator rate and the internal structural changes of this indicator (an analogue of mass in physics [9]):

$$
p(\tau, t)=\mathrm{C}(\tau) V(t) .
$$

Based on the impulse response, we compose the following nonlinear differential equation with the function of the external action $F_{\text {ext }}$ in the form

$$
\frac{d p(\tau, t)}{d t}=\alpha(X) V^{b}+F_{\text {ext }},
$$

where $\alpha(X)$ is the resistance function of the levels, depending on the level at which the indicator is located; $b$ - the constant taking values 1 or 2 .

Next, using this equation, we compare the power characteristics, i.e. $d p / d t$ and $\alpha(X) V^{b}$. The analogy of the inertial force describes the ability of an indicator to change its rate at a given time due to both the influence of other parameters and without any particular influence. This characteristic makes it possible to track the direction of movement of any indicator. The resistance of levels shows their ability to keep the indicator, thus providing qualitative description of the crisis level. Thus, when $d p / d t>\alpha(X) V^{b}$, the indicator changes its trend from a decrease to an increase; when $d p / d t=\alpha(X) V^{b}$, the indicator remains within the same level; and when $d p / d t<\alpha(X) V^{b}$, the indicator continues to decrease.

These characteristics, presented in Table 3 , describe the main parameters of modulus change (sustainable development, directional change, leaps between crisis levels).

Table 3. Main characteristics of the economic potential by adjustment modules.

\begin{tabular}{|l|c|c|c|}
\hline \multirow{2}{*}{ Indicators } & \multicolumn{3}{|c|}{ Indicator state characteristics } \\
\cline { 2 - 4 } & $\begin{array}{c}\text { Average rate of } \\
\text { change. \% }\end{array}$ & $\begin{array}{c}\text { Average value of the } \\
\text { stability function }\end{array}$ & $\begin{array}{c}\text { Average value of the } \\
\text { impulse }\end{array}$ \\
\hline \multicolumn{3}{|c|}{ Innovation potential } \\
\hline $\left.\begin{array}{l}\text { Share of organizations } \\
\text { implementing } \\
\text { technological. } \\
\text { organizational. } \\
\begin{array}{l}\text { marketing innovations } \\
\text { in the total number of } \\
\text { observed organizations. } \\
\%\end{array}\end{array}\right)$ & 9.597548 & \\
\hline $\begin{array}{l}\text { The number of } \\
\text { personnel engaged in } \\
\text { research and } \\
\text { development. to the } \\
\text { total number of } \\
\text { employees. \% }\end{array}$ & 0.673684 & & \\
\hline
\end{tabular}




\begin{tabular}{|l|l|l|l|}
\hline $\begin{array}{l}\text { Cost of technological } \\
\text { innovation to GRP. \% }\end{array}$ & -0.07067 & -0.1774 & -0.04947 \\
\hline \multicolumn{2}{|c|}{ Investing potential } & -0.46333 \\
\hline $\begin{array}{l}\text { Reverse indicator of } \\
\text { depreciation of fixed } \\
\text { assets } * \text { ) }\end{array}$ & -0.66189 & -30.2059 & 0.110179 \\
\hline $\begin{array}{l}\text { The ratio of investments } \\
\text { in the economy to GRP. } \\
\%\end{array}$ & 0.157399 & 3.213568 & 0.081053 \\
\hline $\begin{array}{l}\text { Growth rate of } \\
\text { investment in fixed } \\
\text { assets compared to the } \\
\text { previous year. \% }\end{array}$ & 0.115789 & 0.886902 & -0.21368 \\
\hline $\begin{array}{l}\text { Labor force } \\
\text { participation rate of the } \\
\text { population aged 15-72. } \\
\%\end{array}$ & -0.30526 & -20.5106 & \\
\hline $\begin{array}{l}\text { Employed population } \\
\text { with secondary } \\
\text { education. to the total } \\
\text { employed population. } \\
\%\end{array}$ & -0.08947 & -4.34216 & -0.06263 \\
\hline $\begin{array}{l}\text { Employed population } \\
\text { with higher education. } \\
\text { to the total employed } \\
\text { population. \% }\end{array}$ & 0.689474 & -0.07895 & 0.110526 \\
\hline $\begin{array}{l}\text { Coefficient of migration } \\
\text { growth per 10.000 } \\
\text { people. relative units }\end{array}$ & 0.157895 & 16.15782 & 0.482632 \\
\hline
\end{tabular}

*Note: The inverse indicator of the degree of depreciation of fixed assets.

The authors chose three characteristics: rate of change, stability function and impulse response. The rate of change has a large positively directional impact on innovation and human potential, which makes it possible to get an assessment when overcoming not only one, but also two crisis levels. This is due to the fact that the indicator does not lose its speed properties even at more than one transition level. The function of stability allows us to assert the presence of a weak bifurcation of the selected indicators and their ability to return to their original state. The impulse response reveals the inertial ability to change the trend of the indicator within one crisis level.

\section{A mathematical model for calculating the generalized value of economic development and economic potential and results}

Economic development consists of the following three components (modules): innovation potential, investment potential and human potential. Therefore, for calculations, the following steps were used: obtaining a temporary generalized value for each of the three components; determination of their weights; and calculation of the generalized temporary coefficient of economic development.

To this end, let us apply the CES function method [10], which can be extended to 3 or more variables. This method is based on the function 


$$
\mathrm{R}\left(x_{1}, \ldots, x_{n}\right)=A\left(\sum_{i} c_{i} x_{i}^{\alpha}\right)^{\frac{\beta}{\alpha}},
$$

where $x_{i}$ is the value of the indicator for one of the three modules; the sum of the $c_{i}$ coefficients is 1 .

This function is approximated by the following time dependence

$$
\mathrm{R}\left(x_{1}, \ldots, x_{n}\right)=\sum_{i} a_{i}(t) r_{i}\left(x_{i}\right),
$$

$r_{i}\left(x_{i}\right)$ is one of the components of the module (indicators) or the module as a whole (potential), $a_{i}(t)$ is a temporary weighting factors of the potentials or their indicators.

Using formulas (4) and (5), the main characteristics of potential and economic development were calculated for the example of the Sverdlovsk region (Table 4).

Table 4. Generalized assessment of the well-being of an individual in the territory of residence (on

\begin{tabular}{|c|c|c|c|c|c|c|c|}
\hline Indicators & 2008 & 2009 & 2010 & 2016 & 2017 & 2018 & 2019 \\
\hline \multicolumn{8}{|c|}{ Sverdlovsk Oblast } \\
\hline $\begin{array}{l}\text { I. Index } \\
\text { citizen wellbeing in } \\
\text { the territory of } \\
\text { residence (according } \\
\text { to statistics. } \\
\text { normalized } \\
\text { assessment) } \\
\end{array}$ & $\begin{array}{l}1.12 \\
\mathrm{C} 1\end{array}$ & $\begin{array}{l}1.21 \\
\mathrm{C} 1\end{array}$ & $\begin{array}{l}1.01 \\
\mathrm{C} 1\end{array}$ & $\begin{array}{l}0.85 \\
\text { PC3 }\end{array}$ & $\begin{array}{l}0.89 \\
\text { PC3 }\end{array}$ & $\begin{array}{l}0.91 \\
\text { PC3 }\end{array}$ & $\begin{array}{l}0.91 \\
\text { PC3 }\end{array}$ \\
\hline \multicolumn{8}{|c|}{ Corrective modules: } \\
\hline $\begin{array}{lr}\text { Economic } & \text { potential } \\
\text { (general } & \text { correction } \\
\text { factor) } & \end{array}$ & 0.77 & 1.19 & 1.23 & 1.19 & 1.21 & 1.23 & 1.23 \\
\hline \multicolumn{8}{|l|}{ Including: } \\
\hline Innovation potential & 0.95 & 1.04 & 0.95 & 1.04 & 0.89 & 0.90 & 1.09 \\
\hline Investing potential & 0.73 & 1.17 & 0.66 & 1.15 & 1.16 & 0.75 & 1.23 \\
\hline Human potential & 0.63 & 0.65 & 1.31 & 0.63 & 0.65 & 1.34 & 1.38 \\
\hline $\begin{array}{l}\text { Economic } \\
\text { development (general } \\
\text { correction factor) }\end{array}$ & 0.90 & 1.06 & 0.84 & 1.11 & 0.88 & 1.10 & 1.11 \\
\hline $\begin{array}{ll}\text { Overall adjustment } \\
\text { factor }\end{array}$ & 0.69 & 1.26 & 1.03 & 1.31 & 1.07 & 1.35 & 1.36 \\
\hline $\begin{array}{l}\text { II. Index citizen } \\
\text { wellbeing in the } \\
\text { territory of residence } \\
\text { with adjustments }\end{array}$ & $\begin{array}{l}0.78 \\
\text { PC3 }\end{array}$ & $\begin{array}{l}1.52 \\
\mathrm{C} 2\end{array}$ & $\begin{array}{l}1.04 \\
\mathrm{C} 1\end{array}$ & $\begin{array}{l}1.11 \\
\mathrm{C} 1\end{array}$ & $\begin{array}{l}0.95 \\
\text { PC3 }\end{array}$ & $\begin{array}{l}1.23 \\
\mathrm{C} 1\end{array}$ & $\begin{array}{l}1.24 \\
\mathrm{C} 1\end{array}$ \\
\hline \multicolumn{8}{|c|}{ Chelyabinsk Oblast } \\
\hline $\begin{array}{l}\text { I. Index } \\
\text { citizen wellbeing in } \\
\text { the territory of } \\
\text { residence (according } \\
\text { to statistics. } \\
\text { normalized } \\
\text { assessment) } \\
\end{array}$ & $\begin{array}{c}1.22 \\
\mathrm{C} 1\end{array}$ & $\begin{array}{l}1.31 \\
\mathrm{C} 1\end{array}$ & $\begin{array}{l}1.203 \\
\mathrm{C} 1\end{array}$ & $\begin{array}{l}1.059 \\
\mathrm{C} 1\end{array}$ & $\begin{array}{l}0.935 \\
\text { PC3 }\end{array}$ & $\begin{array}{l}0.968 \\
\text { PC3 }\end{array}$ & $\begin{array}{l}0.992 \\
\text { PC3 }\end{array}$ \\
\hline Corrective modul & & & & & & & \\
\hline
\end{tabular}
the example of the subjects of the Ural Federal District). 


\begin{tabular}{|c|c|c|c|c|c|c|c|}
\hline $\begin{array}{l}\begin{array}{l}\text { Economic } \\
\text { (general } \\
\text { factor) }\end{array} \\
\end{array}$ & 0.74 & 1.21 & 1.22 & 1.20 & 1.22 & 1.23 & 1.25 \\
\hline \multicolumn{8}{|l|}{ Including: } \\
\hline Innovation potential & 1.05 & 0.94 & 1.05 & 1.03 & 0.90 & 0.90 & 1.09 \\
\hline Investing potential & 0.68 & 1.20 & 1.26 & 1.17 & 1.22 & 0.70 & 1.26 \\
\hline Human potential & 0.60 & 0.62 & 1.35 & 0.59 & 0.66 & 1.31 & 1.39 \\
\hline $\begin{array}{l}\text { Economic } \\
\text { development (general } \\
\text { correction factor) }\end{array}$ & 0.89 & 1.04 & 0.87 & 1.08 & 0.89 & 0.90 & 1.10 \\
\hline $\begin{array}{l}\text { Overall adjustment } \\
\text { factor }\end{array}$ & 0.67 & 1.26 & 1.07 & 1.30 & 1.08 & 1.11 & 1.37 \\
\hline $\begin{array}{l}\text { II. Index citizen } \\
\text { wellbeing in the } \\
\text { territory of residence } \\
\text { with adjustments }\end{array}$ & $\begin{array}{l}0.81 \\
\text { PC3 }\end{array}$ & $\begin{array}{l}1.65 \\
\mathrm{C} 2\end{array}$ & $\begin{array}{l}1.28 \\
\mathrm{C} 1\end{array}$ & $\begin{array}{l}1.37 \\
\mathrm{C} 1\end{array}$ & $\begin{array}{l}1.01 \\
\mathrm{C} 1\end{array}$ & $\begin{array}{l}1.07 \\
\mathrm{C} 1\end{array}$ & $\begin{array}{l}1.36 \\
\mathrm{C} 1\end{array}$ \\
\hline \multicolumn{8}{|c|}{ Khanty-Mansi Autonomous Okrug } \\
\hline $\begin{array}{l}\text { I. Index citizen } \\
\text { wellbeing in the } \\
\text { territory of residence } \\
\text { (according to } \\
\text { statistics. normalized } \\
\text { assessment) }\end{array}$ & $\begin{array}{c}1.057 \\
\mathrm{C} 1\end{array}$ & $\begin{array}{c}1.163 \\
\mathrm{C} 1\end{array}$ & $\begin{array}{c}1.031 \\
\mathrm{C} 1\end{array}$ & $\begin{array}{c}1.107 \\
\mathrm{C} 1\end{array}$ & $\begin{array}{c}1.133 \\
\mathrm{C} 1\end{array}$ & $\begin{array}{l}1.13 \\
\mathrm{C} 1\end{array}$ & $\begin{array}{l}1.14 \\
\mathrm{C} 1\end{array}$ \\
\hline \multicolumn{8}{|l|}{ Corrective modules: } \\
\hline $\begin{array}{lr}\text { Economic } & \text { potential } \\
\text { (general } & \text { correction } \\
\text { factor) } & \\
\end{array}$ & 1.22 & 1.22 & 1.22 & 0.78 & 0.81 & 1.18 & 1.20 \\
\hline \multicolumn{8}{|l|}{ Including: } \\
\hline Innovation potential & 1.02 & 1.02 & 1.03 & 1.02 & 0.95 & 0.96 & 1.03 \\
\hline Investing potential & 0.75 & 1.21 & 1.25 & 1.19 & 0.78 & 0.83 & 1.17 \\
\hline Human potential & 1.38 & 0.58 & 1.39 & 0.56 & 1.31 & 1.33 & 1.39 \\
\hline $\begin{array}{l}\text { Economic } \\
\text { development (general } \\
\text { correction factor) }\end{array}$ & 0.89 & 1.07 & 1.08 & 0.91 & 1.08 & 1.10 & 1.11 \\
\hline $\begin{array}{l}\text { Overall adjustment } \\
\text { factor }\end{array}$ & 1.09 & 1.30 & 1.32 & 0.71 & 0.87 & 1.30 & 1.33 \\
\hline $\begin{array}{l}\text { II. Index citizen } \\
\text { wellbeing in the } \\
\text { territory of residence } \\
\text { with adjustments }\end{array}$ & $\begin{array}{l}1.15 \\
\mathrm{C} 1\end{array}$ & $\begin{array}{l}1.52 \\
\mathrm{C} 2\end{array}$ & $\begin{array}{l}1.36 \\
\mathrm{C} 1\end{array}$ & $\begin{array}{l}0.79 \\
\text { PC3 }\end{array}$ & $\begin{array}{l}0.99 \\
\text { PC3 }\end{array}$ & $\begin{array}{l}1.47 \\
\mathrm{C} 2\end{array}$ & $\begin{array}{l}1.52 \\
\mathrm{C} 2\end{array}$ \\
\hline \multicolumn{8}{|c|}{ Yamalo-Nenets Autonomous Okrug } \\
\hline $\begin{array}{l}\text { I. Index citizen } \\
\text { wellbeing in the } \\
\text { territory of residence } \\
\text { (according to } \\
\text { statistics. normalized } \\
\text { assessment) }\end{array}$ & $\begin{array}{c}1.263 \\
\mathrm{C} 1\end{array}$ & $\begin{array}{c}1.304 \\
\mathrm{C} 1\end{array}$ & $\begin{array}{c}1.128 \\
\mathrm{C} 1\end{array}$ & $\begin{array}{c}1.199 \\
\mathrm{C} 1\end{array}$ & $\begin{array}{c}1.199 \\
\mathrm{C} 1\end{array}$ & $\begin{array}{c}1.167 \\
\mathrm{C} 1\end{array}$ & $\begin{array}{c}1.172 \\
\mathrm{C} 1\end{array}$ \\
\hline \multicolumn{8}{|l|}{ Corrective modules: } \\
\hline $\begin{array}{lr}\text { Economic } & \text { potential } \\
\text { (general correction } \\
\text { factor) }\end{array}$ & 0.82 & 1.17 & 1.17 & 0.78 & 1.21 & 0.78 & 1.20 \\
\hline \multicolumn{8}{|l|}{ Including: } \\
\hline Innovation potential & 0.98 & 1.02 & 1.03 & 1.02 & 0.95 & 0.95 & 1.05 \\
\hline Investing potential & 0.60 & 1.29 & 1.31 & 0.61 & 1.27 & 0.72 & 1.20 \\
\hline
\end{tabular}




\begin{tabular}{|c|c|c|c|c|c|c|c|}
\hline Human potential & 1.11 & 0.81 & 1.17 & 1.24 & 1.30 & 1.33 & 1.34 \\
\hline $\begin{array}{l}\text { Economic } \\
\text { development (general } \\
\text { correction factor) }\end{array}$ & 1.01 & 0.97 & 1.02 & 1.03 & 1.05 & 1.08 & 1.10 \\
\hline $\begin{array}{l}\text { Overall adjustment } \\
\text { factor }\end{array}$ & 0.83 & 1.13 & 1.20 & 0.81 & 1.27 & 0.84 & 1.32 \\
\hline $\begin{array}{l}\text { II. Index citizen } \\
\text { wellbeing in the } \\
\text { territory of residence } \\
\text { with adjustments }\end{array}$ & $\begin{array}{l}1.05 \\
\mathrm{C} 1\end{array}$ & $\begin{array}{l}1.48 \\
\mathrm{C} 2\end{array}$ & $\begin{array}{l}1.35 \\
\mathrm{C} 1\end{array}$ & $\begin{array}{l}0.97 \\
\text { PC3 }\end{array}$ & $\begin{array}{l}1.52 \\
\mathrm{C} 2\end{array}$ & $\begin{array}{l}0.98 \\
\text { PC3 }\end{array}$ & $\begin{array}{l}1.55 \\
\mathrm{C} 2\end{array}$ \\
\hline \multicolumn{8}{|c|}{ Tyumen Oblast (south)* } \\
\hline $\begin{array}{l}\text { I. Index } \\
\text { citizen wellbeing in } \\
\text { the territory of } \\
\text { residence (according } \\
\text { to statistics. } \\
\text { normalized } \\
\text { assessment) }\end{array}$ & $\begin{array}{c}1.145 \\
\mathrm{C} 1\end{array}$ & $\begin{array}{c}1.245 \\
\mathrm{C} 1\end{array}$ & $\begin{array}{c}1.055 \\
\mathrm{C} 1\end{array}$ & $\begin{array}{c}1.016 \\
\mathrm{C} 1\end{array}$ & $\begin{array}{c}1.012 \\
\mathrm{C} 1\end{array}$ & $\begin{array}{c}1.102 \\
\mathrm{C} 1\end{array}$ & $\begin{array}{c}1.084 \\
\mathrm{C} 1\end{array}$ \\
\hline \multicolumn{8}{|l|}{ Corrective modules: } \\
\hline $\begin{array}{lr}\text { Economic } & \text { potential } \\
\text { (general correction } \\
\text { factor) }\end{array}$ & 0.72 & 1.25 & 1.27 & 1.32 & 0.64 & 0.66 & 1.30 \\
\hline \multicolumn{8}{|l|}{ Including: } \\
\hline Innovation potential & 1.02 & 1.02 & 1.04 & 1.04 & 0.90 & 0.90 & 1.09 \\
\hline Investing potential & 0.68 & 1.27 & 0.69 & 1.27 & 0.66 & 0.70 & 1.18 \\
\hline Human potential & 0.52 & 1.45 & 1.45 & 0.34 & 0.37 & 0.38 & 1.62 \\
\hline $\begin{array}{l}\text { Economic } \\
\text { development (general } \\
\text { correction factor) }\end{array}$ & 0.36 & 1.53 & 0.39 & 1.12 & 1.13 & 0.84 & 1.11 \\
\hline $\begin{array}{l}\text { Overall adjustment } \\
\text { factor }\end{array}$ & 0.66 & 1.91 & 0.50 & 1.49 & 0.72 & 0.55 & 1.44 \\
\hline $\begin{array}{l}\text { II. Index citizen } \\
\text { wellbeing in the } \\
\text { territory of residence } \\
\text { with adjustments }\end{array}$ & $\begin{array}{l}0.75 \\
\text { PC3 }\end{array}$ & $\begin{array}{c}2.38 \\
\mathrm{C} 3\end{array}$ & $\begin{array}{l}0.52 \\
\text { PC2 }\end{array}$ & $\begin{array}{l}1.51 \\
\mathrm{C} 2\end{array}$ & $\begin{array}{l}0.73 \\
\text { PC3 }\end{array}$ & $\begin{array}{l}0.61 \\
\mathrm{PC} 2\end{array}$ & $\begin{array}{l}1.56 \\
\mathrm{C} 2\end{array}$ \\
\hline \multicolumn{8}{|c|}{ Kurgan Oblast } \\
\hline $\begin{array}{l}\text { I. Index } \\
\text { citizen wellbeing in } \\
\text { the territory of } \\
\text { residence (according } \\
\text { to statistics. } \\
\text { normalized } \\
\text { assessment) }\end{array}$ & $\begin{array}{c}1.267 \\
\mathrm{C} 1\end{array}$ & $\begin{array}{c}1.264 \\
\mathrm{C} 1\end{array}$ & $\begin{array}{c}1.267 \\
\mathrm{C} 1\end{array}$ & $\begin{array}{c}1.222 \\
\mathrm{C} 1\end{array}$ & $\begin{array}{c}1.178 \\
\mathrm{C} 1\end{array}$ & $\begin{array}{c}1.212 \\
\mathrm{C} 1\end{array}$ & $\begin{array}{c}1.214 \\
\mathrm{C} 1\end{array}$ \\
\hline \multicolumn{8}{|l|}{ Corrective modules: } \\
\hline $\begin{array}{lr}\text { Economic } & \text { potential } \\
\text { (general } & \text { correction } \\
\text { factor) } & \\
\end{array}$ & 0.79 & 0.82 & 1.10 & 0.85 & 1.12 & 1.14 & 1.21 \\
\hline \multicolumn{8}{|l|}{ Including: } \\
\hline Innovation potential & 0.96 & 1.04 & 1.04 & 1.02 & 1.06 & 0.93 & 1.07 \\
\hline Investing potential & 0.58 & 0.73 & 1.11 & 0.79 & 1.10 & 1.21 & 1.32 \\
\hline Human potential & 1.17 & 0.77 & 0.85 & 0.79 & 0.81 & 1.13 & 1.23 \\
\hline $\begin{array}{l}\text { Economic } \\
\text { development (general } \\
\text { correction factor) }\end{array}$ & 0.97 & 0.95 & 0.93 & 0.96 & 1.03 & 1.03 & 1.05 \\
\hline
\end{tabular}




\begin{tabular}{|c|c|c|c|c|c|c|c|}
\hline $\begin{array}{l}\text { Overall adjustment } \\
\text { factor }\end{array}$ & 0.77 & 0.78 & 1.02 & 0.82 & 1.15 & 1.17 & 1.27 \\
\hline $\begin{array}{l}\text { II. Index citizen } \\
\text { wellbeing in the } \\
\text { territory of residence } \\
\text { with adjustments }\end{array}$ & $\begin{array}{l}0.97 \\
\text { PC3 }\end{array}$ & $\begin{array}{l}0.99 \\
\mathrm{PC} 3\end{array}$ & $\begin{array}{c}1.30 \\
\mathrm{C} 1\end{array}$ & $\begin{array}{c}1.01 \\
\mathrm{C} 1\end{array}$ & $\begin{array}{l}1.35 \\
\mathrm{C} 1\end{array}$ & $\begin{array}{l}1.42 \\
\mathrm{C} 2\end{array}$ & $\begin{array}{c}1.54 \\
\mathrm{C} 2\end{array}$ \\
\hline \multicolumn{8}{|c|}{ Ural Federal District } \\
\hline $\begin{array}{l}\text { I. Index citizen } \\
\text { wellbeing in the } \\
\text { territory of residence } \\
\text { (according to } \\
\text { statistics. normalized } \\
\text { assessment) }\end{array}$ & $\begin{array}{c}1.131 \\
\mathrm{C} 1\end{array}$ & $\begin{array}{c}1.304 \\
\mathrm{C} 1\end{array}$ & $\begin{array}{l}1.05 \\
\mathrm{C} 1\end{array}$ & $\begin{array}{l}0.966 \\
\text { PC3 }\end{array}$ & $\begin{array}{l}0.926 \\
\text { PC3 }\end{array}$ & $\begin{array}{c}0.997 \\
\text { PC3 }\end{array}$ & $\begin{array}{l}0.997 \\
\text { PC3 }\end{array}$ \\
\hline \multicolumn{8}{|l|}{ Corrective modules: } \\
\hline $\begin{array}{l}\text { Economic potential } \\
\text { (general correction } \\
\text { factor) }\end{array}$ & 0.77 & 1.20 & 1.21 & 0.77 & 0.77 & 1.22 & 1.22 \\
\hline \multicolumn{8}{|l|}{ Including: } \\
\hline Innovation potential & 0.96 & 1.04 & 1.04 & 1.03 & 0.91 & 0.92 & 1.08 \\
\hline Investing potential & 0.71 & 1.22 & 1.27 & 0.75 & 1.22 & 0.77 & 1.19 \\
\hline Human potential & 0.64 & 0.64 & 1.33 & 0.60 & 0.64 & 1.35 & 1.40 \\
\hline $\begin{array}{l}\text { Economic } \\
\text { development (general } \\
\text { correction factor) }\end{array}$ & 0.86 & 1.09 & 0.86 & 1.08 & 1.09 & 1.10 & 1.11 \\
\hline $\begin{array}{l}\text { Overall adjustment } \\
\text { factor }\end{array}$ & 0.66 & 1.31 & 1.04 & 0.84 & 0.84 & 1.34 & 1.35 \\
\hline $\begin{array}{l}\text { II. Index citizen } \\
\text { wellbeing in the } \\
\text { territory of residence } \\
\text { with adjustments }\end{array}$ & $\begin{array}{l}0.75 \\
\text { PC } 3\end{array}$ & $\begin{array}{l}1.71 \\
\mathrm{C} 2\end{array}$ & $\begin{array}{l}1.10 \\
\mathrm{C} 1\end{array}$ & $\begin{array}{l}0.81 \\
\text { PC3 }\end{array}$ & $\begin{array}{l}0.78 \\
\text { PC } 3\end{array}$ & $\begin{array}{l}1.33 \\
\mathrm{C} 1\end{array}$ & $\begin{array}{l}1.35 \\
\mathrm{C} 1\end{array}$ \\
\hline
\end{tabular}

* Note: The results for the Tyumen region are presented without taking into account the autonomous districts of the Khanty-Mansi Autonomous Okrug and Yamalo-Nenets Autonomous Okrug, which are considered separately.

As a result of the calculations presented above, the deviation of the normalized assessment of the level of individual well-being in the territory of residence, including sharp transitions to more than two crisis levels:

1. In crisis years, the transition to more than one level was identified for the subjects of the Ural Federal District.

2. The abnormal transition in 2009 by more than two levels for the south of the Tyumen region is explained by a non-standard change in the economic development module due to an increase in the ratio of the territory's export to GRP and a decrease in the coefficient of migration growth per 10,000 population. At the same time, the corrective module of human potential had a positive impact on the personal well-being index in the territory of residence in 2018 (PC2). 3. At the same time, when overcoming the thresholds of crisis levels, a weak transformation of the sign of the impulse response of all selected indicators was revealed, which would be considered if there were signs of economic security.

In general, an adjusted index of the citizen wellbeing in the territory of residence was obtained for the Sverdlovsk region (Fig. 1). 


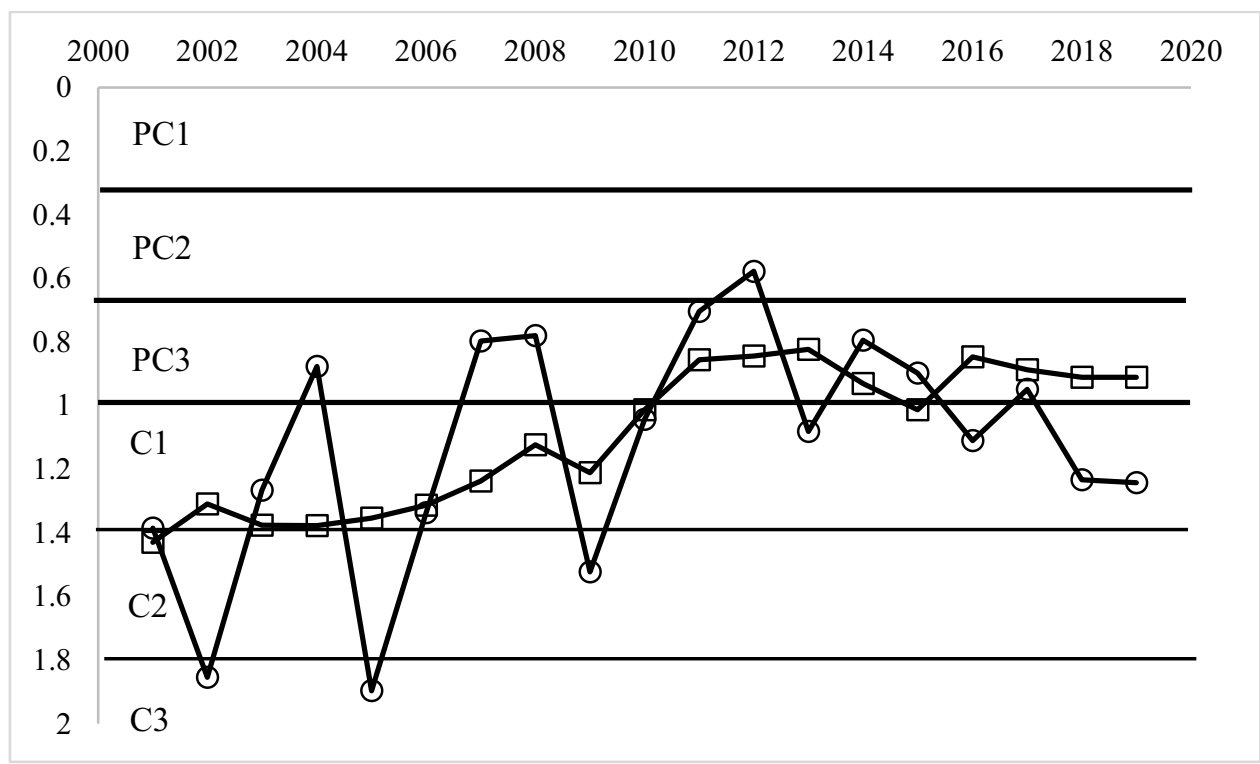

Fig. 1. Temporary trends of the generalized normalized assessment of citizen wellbeing in the territory of residence: the adjusted assessment (- $\left.--_{-}\right)$and according to statistical data (- $\square-\square-$ ) (the example of the Sverdlovsk Oblast).

The adjusted estimate due to the influence of economic development and potential made it possible to distinguish a positive influence within $15-20 \%$, a negative influence within 10 $15 \%$. Stationary behavior was revealed in 2006 and 2010.

\section{Conclusion}

1. A methodology has been developed for adjusting citizen wellbeing in the territory of residence, considering the modules of economic development and the potential of the region, with a breakdown of the latter into three components: innovation potential, investment potential and human potential.

2. Based on the selected three characteristics (rate of change, stability function and impulse response), for the first time, a weak bifurcation of the indicators we selected was revealed, which was expressed in their ability to return to the initial state.

3. It was possible to establish that when overcoming more than two crisis levels during the year, the architectonics of the socio-economic system of the region is preserved in general.

4. It was also revealed that for a more accurate and reliable assessment citizen wellbeing in the territory of residence it is necessary to take into account the presence of one more module (economic security), i.e. the ability of a territory to react without collapse to geopolitical changes. The research results can be used in the current assessment and in forecasting trends in the development of the region.

\section{Acknowledgements}

The article was prepared with the financial support of the RFBR grant No. 19-010-00100 "Harmonization of the population-power-business triad as a basis for progressive socioeconomic development of Russian regions". 


\section{References}

1. International Scientific Conference in HSE. Voprosy Economiki 7, 5-50 (2020) http://doi.org/10.32609/0042-8736-2020-7-5-50

2. Complex methodology for assessing the wellbeing of citizens in the territory of their residence (Institute of Economics of the Ural Branch of RAS, Ekaterinburg, 2017)

3. V.V. Kirzhanova, N.I. Grigorova, E.N. Bobkov, V.N. Kirzhanov, O.V. Sidoryuk, Activity of drug control service in the Russian Federation in 2018-19: Analytical report (NMITS PN named after V.P. Serbsky, Moscow, 2020)

4. M.E. Pozdnyakova, Vestnik of the Russian Fund for Basic Research 2(95), 77-88 (2019) DOI: $10.22204 / 2587-8956-2019-095-02-77-89$

5. Methodology for drug situation control. RF State Anti-Drug Committee, https:/гак.мвд.рф/мониторинг-наркоситуации/metodika

6. A. İșcanoğlu-Çekiç, H. Gültekin, Physica A: Statistical Mechanics and its Applications 525, 978-990 (2019) https://doi.org/10.1016/j.physa.2019.03.074

7. D.W. Boyd, Systems analysis and modeling. A macro-to-micro approach with multidisciplinary applications (Elsevier Inc, 2001)

8. Jing Qin, Jintian Ge, Xinsheng Lu, Physica A: Statistical Mechanics and its Applications 506, 1026-1037 (2018) https://doi.org/10.1016/j.physa.2018.04.068

9. J. Hatutale, S.J.P. Sheefeni, Journal of Emerging Issues in Economics, Finance and Banking 2, 847-857 (2013)

10. T.D. Roger, T.M.D. William, Behav. Res. Methods. 48(2), 783-802 (2016) DOI: 10.3758/s13428-015-0611-2

11. N. Zhang, A. Lin, P. Yang, Physica A: statistical mechanics and its applications 542 (2020) https://doi.org/10.1016/j.physa.2019.122960 